\title{
SOCIAL PRESTIGE OF WOMEN IN MARRIAGE FROM THE PERSPECTIVE OF IMAM KHOMEINI
}

\section{PRESTÍGIO SOCIAL DAS MULHERES NO CASAMENTO DA PERSPECTIVA DO IMAM KHOMEINI}

Seyed Mohsen Razmi ${ }^{1}$

Mustafa Rajaipour ${ }^{2}$

Zahra Biooki ${ }^{3}$

\begin{abstract}
The observance of women's social prestige is of a particular importance considering their increasingly significant rights. The investigation of the women's social prestige from the perspective of Imam Khomeini, as a jurisprudence who founded Islamic Republic of Iran, is of a double significance. The present study evaluates the women's social prestige in marriage from the perspective of Imam Khomeini. Numerous studies have been conducted in the area of Imam Khomeini's approach towards women. However, his highness's perspective about the women's social prestige in marriage and in relation to their spouses has been neglected. The main question of the present study is how women's social prestige can be evaluated in marriage from the perspective of Imam Khomeini? The study is a descriptive-analytical research and uses a library research method to find an answer to the abovementioned question. The article's results indicated that Imam Khomeini (PBUH) believed in the observance of the women's social prestige in relation to their spouses. Based thereon, Imam Khomeini (PBUH)'s perspective about the observance of the wives' prestige in respect to the ultimate goals of marriage includes wives' prestige in regard of their alimony, wives' prestige in being supplied with the necessary needs, supply of food, supply of clothing, supply of house furniture, employment of a maid, supply of the costs of drug and treatment, supply of the cleaning and bathing costs as well as the wives' prestige in employment rights and participation in the economic activities, wives' prestige in going out of the house for getting the required jobs done, observance of the wives' veneration and respect, education right, the right and prestige for the determination of a living place and other related rights and respects.
\end{abstract}

Keywords: Social Prestige, Imam Khomeini (PBUH), Alimony, Education Right, Employment Right

\footnotetext{
${ }^{1}$ Assistant Professor of Jurisprudence and Fundamentals of Islamic Law, Mashhad Branch, Islamic Azad University, Mashhad, Iran. ORCID: https://orcid.org/0000-0002-3853-5348 E-mail: razmi0109@ mshdiau.ac.ir

${ }^{2}$ Assistant Professor of the Department of Jurisprudence and Fundamentals of Islamic Law, Mashhad Branch, Islamic Azad University, Mashhad, Iran. ORCID: https://orcid.org/0000-0001-8857-4831 E-mail: mostafarajae@yahoo.com

${ }^{3}$ Ph.D. Student in Jurisprudence and Law, Mashhad Branch, Islamic Azad University, Mashhad, Iran. ORCID: https://orcid.org/0000-0001-7216-992X E-mail: zahrabiooki@gmail.com
} 


\section{RESUMO}

A observância do prestígio social das mulheres é de particular importância, considerando seus direitos cada vez mais significativos. A investigação do prestígio social das mulheres na perspectiva do Imam Khomeini, como um jurisprudente que fundou a República Islâmica do Irã, é de duplo significado. O presente estudo avalia o prestígio social das mulheres no casamento da perspectiva do Imam Khomeini. Numerosos estudos foram conduzidos na área da abordagem do Imam Khomeini em relação às mulheres. No entanto, a perspectiva de sua alteza sobre o prestígio social das mulheres no casamento e em relação aos seus cônjuges foi negligenciada. A principal questão do presente estudo é como o prestígio social das mulheres pode ser avaliado no casamento a partir da perspectiva do Imam Khomeini? O estudo é uma pesquisa descritivo-analítica e utiliza o método de pesquisa bibliotecária para encontrar uma resposta à questão acima mencionada. Os resultados do artigo indicaram que o Imam Khomeini (PBUH) acreditava na observância do prestígio social das mulheres em relação aos seus cônjuges. Com base nisso, a perspectiva do Imam Khomeini (PBUH) sobre a observância do prestígio das esposas em relação aos objetivos finais do casamento inclui o prestígio das esposas em relação à sua pensão alimentícia, o prestígio das esposas em serem supridas com as necessidades necessárias, fornecimento de alimentação, fornecimento de roupas, fornecimento de móveis para a casa, emprego de empregada doméstica, fornecimento das despesas com medicamentos e tratamento, fornecimento das despesas de limpeza e banho bem como o prestígio das esposas nos direitos trabalhistas e na participação nas atividades econômicas, esposas 'prestígio na saída de casa para realização dos trabalhos exigidos, observância da veneração e respeito das esposas, direito à educação, direito e prestígio pela determinação de moradia e demais direitos e respeitos relacionados.

Palavras-chave: Prestígio social, Imam Khomeini (PBUH), pensão alimentícia, direito à educação, direito ao emprego

\section{INTRODUCTION}

The women's social position and prestige have always been amongst the controversial issues. The evident religion of Islam does not believe in any restriction for the women's involvement in social activities rather it determines criteria and accepts the women's social activities within the limits of the observance of the canonical duties. His Highness Imam Khomeini has ordered in this regard that "this is advertisement that if Islam comes, the women should go and sit at their homes and put a lock on their doors and never come out again! These sayings that are attributed to Islam are wrong. During the early Islamic periods, women joined the armies and attended the battlefields ... of course, some canonical rules are specific to men for their being more proportionate to their statuses; some rulings are specific to women for their being in proportion to their statuses. This does not mean that Islam differently approaches men and women. Men and women are all free to go to university; they are free to vote for someone 
and be voted and elected (MUSAVI KHOMEINI, 2006). As for the women's rights, numerous studies have been done in various dimensions but the women's social prestige is amongst the subjects focused to a lesser degree. Prestige means the social and individual position and respect of every individual and it has been discussed in jurisprudence in chapters like Zakat, marriage, reverence and so forth. By prestige, the human beings' familial and social position and rank is intended (DEHKHODA, 1998). Prestige has been particularly taken into account in the sacred canon (MAKAREM SHIRAZI, 1995; KOLAINI RAZI, 1983 and AROUSI AL-HAWIZI, 1995). The thing dealt with herein is the prestige in the sense of glory and rank; social, familial and individual personality of a person that is supposed to assist an individual in various affairs so that $\mathrm{s} /$ he can administrate his or her life affairs. Social prestige of women in the family affairs and common life is amongst the important dimensions and indicators of the observance of women's rights and it plays an important role in the solidification of the familial and social foundations. Efforts have been made in this article to deal with this important issue from the perspective of His Highness Imam Khomeini (PBUH) as one of the contemporary influential jurisprudents.

\section{WIVES' PRESTIGE IN ALIMONY}

\section{WIVES' PRESTIGE IN THE SUPPLY OF THE NECESSARY NEEDS}

Alimony is the topic specified in jurisprudence with two indices: one of them is more directed towards the domain and extent of the alimony's pervasiveness and the other specifies its quality and level and both of these two indices eventually determine and render enforceable the framework of the "alimony right". The first index elaborates the concept of alimony as a sort of need meaning that alimony includes the cost of the women's necessary and preliminary needs with the persistence of life being pendant on the enjoyment of them. In Tahrir AlWasileh, Imam Khomeini points to the idea that no limit and size has been determined in canon for alimony and enumerates "need" amongst the premises of requiring a husband to the paying of alimony to a woman and orders that: "no amount has been specified for alimony by canon rather the obligor has been required to supply the women with whatever the things they need from food and stew to clothing and bed and carpet and house and maid and instruments needed for drinking, cooking, cleaning and so forth” (MUSAVI KHOMEINI, 1995).

The second index determines the extent of alimony, women's prestige and position meaning that alimony includes the expenditures required by a woman in proportion to her familial position and stance. The constraint "prestige" in the previous statement explicates the 
concept of "need" and specifies that a woman's prestige should be taken into consideration for supplying her with alimony. Based thereon, it is natural that alimony differs in respect to the women's familial position and it is not so that alimony's amount (quality and quantity) be identical in all of the cases (MUSAVI KHOMEINI, 1995).

On the other hand, considering the fact that "prestige" is a relative concept proposed by jurisprudents for the explanation and elucidation of two constraints, namely 1) the region and locality's norms and 2) prestige of father or husband's family, the locality's norm has been agreed by the great exegetes from amongst the two foresaid constraints. For instance, His Highness Imam (PBUH) orders in regard of the alimony's limits that "in regard of the question that what might be included by food, the scale is what is commonly provided as food in the couples' residence town". However, in regard of the second constraint, i.e. familial prestige, there are two kinds of perspectives. The first perspective which is more seen amongst the antecedent jurisprudents holds the consideration of a wife's prestige in respect to her paternal family. The same perspective can be also inferred from His Highness Imam Khomeini (PBUH)'s expressions in Tahrir Al-Wasileh where his highness orders that "providing a wife with bondswoman and maids and servants becomes compulsory only when she enjoys a high prestige, magnificence and glory and also when she is from a family that has never been without a servant".

A number of jurisprudents believe that alimony and life costs of a woman should be consistent with her prestige and the husband's financial affordability. According to this theory, the wife's status should be taken into account and her social status and familial prestige should be considered in determining the alimony. Many of the jurisprudents support this theory and consider the coordination between a woman's cost of living and her prestige (MOHAQQEQ HELLI, 1989; ALLAMEH HELLI, 1989; JABA'EI AMELI, 1990 AND BAHA'EI, 2000). Imam Khomeini, as well, orders in this regard that alimony's amount has not been specified by canon rather the maxim is that the wives should be provided with what they need such as food and stew and so forth; the types of the wives' needs are specified by their living places' norms “(KHOMEINI, 1990).

In fact, Imam Khomeini realizes alimony as including all the instruments needed by a woman according to her degree of civilization, life environment, physical status and psychological situation. Based on what was mentioned, a husband should shoulder the costs of his wife and children as the family's head. The change in the lifestyle brings about new needs every day. These needs cannot be limited within a specific framework and the judgment should be delegated incumbently to the norms and common laws. 


\section{WIFE'S PRESTIGE IN FOOD SUPPLIES:}

Atop of all the cases included by alimony, food is of a great importance. Nourishment includes all the drinkables and edibles. Besides meals like bread and rice, food also includes stew as an obligatory edible material (MOHAQQEQ DAMAD, 1997 AND AMELI, 1983) and it has to be to the amount that the wife and the children's hunger is satisfied (Musavi Khomeini, 1995).

According to some jurists, food means anything eaten and drunk by human beings for survival and striving (EMAMI, 1998). Some jurisprudents have also required the supply of fruits, including date, raisin, and so forth (AMELI, 1999). It seems that fruits are also considered as a sort of nourishment where they are abundantly found quite against the places wherein fruits are rare hence viewed as luxurious foods eaten by a few of the people in which case fruits are excluded from the alimony's subjects (FERESHTIAN, 2002 AND HA'ERI SHAH BAGH, 1997).

Anyhow, the women's prestige and position and their seasonal needs are effective in determining the alimony allocated to the nourishment (DAYYANI, 2000, p.135). The sure thing is that a wife should be provided with a sort of food to which she is accustomed and habited otherwise she may be exposed to a type of loss (HA'ERI SHAH BAGH1997: NAJAFI, 1947AND MUSAVI KHOMEINI, 1995).

If women are provided with edibles in a raw and unprepared manner, the husband is obliged to supply the cooking costs or he is obliged to provide the wife with the cooking instruments and means in a proportionate and common manner. For example, in regard of bread, a husband should either supply his wife with baked bread (NAJAFI, 1947) or, if he provides her with wheat, he has to shoulder the costs of milling the wheat into flour and its cooking.

\section{WIFE'S PRESTIGE IN CLOTHING SUPPLY:}

The term "Albaseh" is the irregular plural form of "Lebas" meaning what a person may put on. In the narrations and the scientists' words, besides incorporating the garments such as shirts and pants, clothing includes shoes and socks and hats, as well (EMAMI1998; DAYYANI, 2000; AMELI1999 AND NAJAFI, 1947). Outfits should be in proportion to various seasons of year and women's social position (AMELI,1999 AND MUSAVI KHOMEINI, 1995). In case that a women's prestige makes it expedient for her to have numerous sets of clothing for various 
ceremonies, the husband is obliged to provide her with all kinds of them. However, a husband is free in providing the wife with tailored clothing or giving her the (equivalent) price so that she can procure clothing for herself. If the husband provides her with fabric, he has to pay the price of its tailoring and sewing. In the meanwhile, in case that putting on clothes in winter does not suffices the wife's warming, the husband should procure firewood and coal for the heating of the house (AMELI,1999).

\section{WIFE'S PRESTIGE IN THE SUPPLY OF HOUSE FURNITURE:}

House furniture is usually realized as encompassing carpet and living instruments such as blanket and quilt; however, it appears that the cooking utensils and other tools are also to be viewed as house furniture. In more precise terms, house furniture includes all the instruments that are required for a life in proportion to the wife's prestige. Some objects like carpet, quilt, utensils and lamps are needed for the lives of all the social classes though their materials and types and amounts might be different. Some objects depend on the wife's life level and the local norms and customs and the woman's prestige such as refrigerator and cooler; if dish-washing machine or microwave oven are in proportion to the wife's prestige, they should be also procured. Thus, the idea that a wife should bring dowry from her father's house is wrong and not legally substantiable. This is while article 1107 of the civil law rules the opposite and stipulates that the house furniture is amongst the wife's alimony hence procurable by husband. Some jurisprudents have required the procurement of the house instruments under the general title of "Athath Al-Bayt" [house furniture] (AMELI, 1999; MUSAVI KHOMEINI, 1995 AND NAJAFI, 1947).

Anyway, it can be understood from article 1107 of the civil law that a wife's needs are commonly the scale of the alimony and, in this regard, the costs of the drugs and treatment should be also considered as part of alimony. So, considering the alimony's scale in the abovementioned article, all the expenditures that should be presently made for the spending of life, including the treatment costs and so on, can be added to the aforementioned cases.

Considering the aforesaid materials, it becomes clear that the house furniture is of two types: instruments related to cooking and procurement of food such as stove and containers and utensils as well as the tools needed for residence in and use of a house such as carpet and quilt with the first kind being the instruments of preparing food; as it was mentioned in the first section on food supply, a husband is obliged to provide his wife with the means of cooking in case of not supplying her with ready food. The second kind is considered as the house 
instruments and because a husband is obliged to prepare a house, he is also required to provide the house furniture otherwise the objective is not accomplished and the wife's optimal use of the house cannot take place.

\section{WIFE'S PRESTIGE IN EMPLOYING A MAID:}

In the far past and at the time that the slavery had not been yet uprooted, there were different discussions about "maids and bondsmen and bondswomen" as servants of a person's wife. However, by maid in the present article, a bondsman or a bondswoman capable of doing the house works is intended. Corresponding to article 1107 of the civil law, a husband should hire a servant for his wife in two cases:

1) If the hiring of a servant is found necessary for the wife in regard of her social position and prestige. The distinct example of such a necessity is a case in which a wife has previously had a servant at her father's house and this condition has been approved by most of the jurisprudents (NAJAFI, 1947 AND MUSAVI KHOMEINI, 1995). In this case, as well, the servant should be like house and clothing in proportion to the wife's social status in her father's house (DAYYANI,2000; FERESHTIAN, 2002).

2) When a wife happens to be needful of a servant for getting her personal affairs done such as in sickness, disability, pregnancy and so forth; in these cases, it is not necessary for the husband to hire a servant in proportion to the wife's social stance rather the mere satisfaction of her needs is sufficient. For instance, if a wife gives birth to several infants, the husband should hire another person for the wife so as to supply her with her needs or he himself can begin serving her and meeting her needs or the woman can voluntarily perform her personal tasks in which case the wife does not have the right to demand the alimony for hiring the servant from her husband (DAYYANI,2000).

Some Imamiyyeh jurisprudents realize the existence of a servant as being similar to the necessity of the alimony for the other relatives and believe that in the same way that the other relatives' alimony is necessary in case that the husband can financially afford it, the hiring of a servant is also necessary if the husband can financially afford it; this is quite unlike food, clothing and housing alimony that has to be obligatorily supplied by the husband. Article 1107 of the civil law does not realize a husband's financial affordability as being necessary for the hiring of a servant.

It seems that it is better for us to make a distinction here. In the latter case, i.e. a wife's need for nursing and care, the servant is amongst the other necessary needs of the husband but 
in the former case, hiring a servant due to the social prestige and position, the hiring of a servant should be opined necessary when the husband can afford it because in this case the wife's need for a servant is not to the extent that the hiring of a servant can be considered as one of the life's prerequisites and the husband can be required to hire one whether financially affording or not affording it. The norms and customs do not oblige the husband to hire a servant in such cases and do not realize it compulsory for a husband to hire a maid rather a servant is in this case considered as one of the life's formalities and viewed as just a luxurious undertaking and this case is different from the other needs and requirements of a wife such as food, clothing and housing.

After the investigation of the examples that have been explicitly mentioned in the law, the forthcoming part tries evaluating the specimens that have not been explicitly mentioned and are areas of the jurists and jurisprudents' discrepancies.

\section{WIFE'S PRESTIGE IN DRUG AND TREATMENT COSTS'SUPPLY:}

No reference has been made to the compulsoriness of the drug and treatment costs in $\bar{A} Y \bar{A} T$ and narrations; Imam Khomeini (PBUH) divides the costs of drug and treatment into two sections: the common drugs that are frequently needed and the individuals may be less frequently needless of them that are enumerated amongst the alimony subjects but the apparent thing is that the costs of the difficult-to-cure diseases that rarely occur cannot fall in the alimony's inclusion circle, especially if the husband is obliged to spend a lot of money for the curing of these diseases (MUSAVI KHOMEINI, 1995). Some jurists (JA'AFARI LANGARUDI, 1989 AND KATOUZIYAN, 1996) have realized the costs of drugs and treatment as being included by alimony subjects and some others (EMAMI, 1998) have taken a silent position in this regard. The individuals who have opined the compulsoriness of a husband's shouldering of the costs of drugs and treatment, physician, phlebotomy and so forth reason that these serve the protection of a wife's life and the protection of a wife's life is obligatory because it is the duty of every Muslim to protect the life of a person at risk. Now, if a wife is found having been inflicted with a difficult-to-cure disease, who would be closer and more deserving than her husband for saving her life (MIRSHAMSI, 2001).

Cooperation and collaboration between Muslims as the instructions and affairs highly focused by Islam, as well, render it expedient for a husband to dash for the assisting of his sick wife; so, the aforementioned costs are to be obligatorily shouldered by the husband. That is because such a criterion as a husband's well treating of his wife makes it necessary for the 
husband to pay her the alimony allocated to the costs of drug and treatment. This important issue can be illuminated according to the holy Quran's commands; in the holy Quran and the $\bar{A} Y \bar{A} T$ that express things about women's affairs, the term "well-treating” has been applied seventeen times and husbands have been recommended to commonly and well treat their wives for fourteen times. Common treating of the wives in regard of endowments and alimony is very vast and it includes all the wife's needs for life and striving.

\section{WIFE'S PRESTIGE IN CLEANING AND BATHING COSTS'SUPPLY:}

The costs of cleaning and its instruments and tools, including soap, cedarwood powder and so forth have been opined by nearly all jurisprudents (KATOUZIYAN, 1996; AMELI, 1999 AND NAJAFI, 1947) amongst the alimony topics but, meanwhile ruling the necessity of the cleaning costs' supply, some jurisprudents have decreed that the bathing costs are not compulsory except for some cases like coldness (NAJAFI, 1947). Imam Khomeini (PBUH) has explicitly opined that the bathing cost is absolutely compulsory and expresses that the bathing wage is amongst the costs a wife is entitled to whether for washing her body or for cleaning in cases that washing the body and cleaning is not commonly exercised in one's own house or a person is excused from doing so or when it is difficult due to the coldness of the weather and so forth (EMAMI, 1998 AND KATOUZIYAN, 2012).

Jurists, as well, have expressed their agreement with the recent idea, i.e. compulsoriness of the husband's supply of the bating costs, and they have explicitly presented their opinion and some others have not explicitly mentioned this opinion because of consideration of this cost as one of the women's daily needs. It can be finally concluded according to the multiplicity of the ideas in this regard that the bathing and cleaning costs are amongst the alimony subjects but they should be made within common limits and the husbands are obliged to supply the aforesaid costs in respect to the common laws and habits (NAJAFI, 1947).

It seems that we can make this conclusion based on the previous discussions that the wives' needs are of two kinds:

1) Necessary and vital needs: these have been considered amongst the primary subjects of alimony the supply of which is compulsory for a husband such as food, clothing and housing.

2) The miscellaneous needs: these are almost of second degree and the husbands are obliged to supply them to the extent realized expedient by the customs and norms such as 
servant, comfortability tools and makeup instruments, perfumes and luxurious and ornamental objects.

it is evident according to what was mentioned and the classifications that were presented that the level and quality of alimony are buoyant concepts and that they can rise and fall with the changes in the husband's affordability and the wife's expectations. Thus, if a husband provides his wife with low level of sustenance and life even with financial affordability of higher levels thereof and it is found inconsistent with both the husband's facilities and the wife's prestige, such a meagerness is undoubtedly envisioned as a maltreatment of the wife and the husband can be required to improve the alimony's quality.

\section{WIFE'S PRESTIGE IN RIGHTS OF EMPLOYMENT AND PARTICIPATION IN THE ECONOMIC ACTIVITIES:}

A glance at the notions, expressions and life of his highness Imam (PBUH) makes it clear that his highness realized women as not only being qualified for employment and participation in the economic activities but also capable of getting involved, in a higher horizon, in the full-scale construction of the country for his highness has repeatedly encouraged the women to construction and reconstruction of the country and elimination of the privations. Amongst the pervasive participation scenes is the scene of the full-scale construction of the country and society and nobody should and can doubt that perfect success is achievable without the active presence of the women in the Islamic society. In this regard, as well, his highness Imam has made a lot of recommendations: all of the Iranian nation, all of the Iranian nation, whether man or woman, should reconstruct these ruins that have been left for us. Things cannot be corrected only by the men's hands; men and women should cooperate for the construction of these ruins (MUSAVI KHOMEINI, 1990). Lion-hearted and committed women should keep pace with the dear men to reconstructed the darling Iran in the same way that they have engaged in the reconstruction of their own selves through science and culture and you cannot find a city or a village unless there have been cultural and scientific gatherings formed of the committed women and prestigious Islamic ladies (MUSAVI KHOMEINI, 1990). Considering the abovementioned materials, His Highness Imam's perspective about the wives' employment right and participation in the economic activities can be expressed in the following words based on his highness's utterances, notions and answers to the questions he had been asked: his highness's opinion about women's employment is like that opined by the other great Imamiyyeh jurisprudents and that is reflective of the fact that the jurisprudents have not dealt 
with the husband's will for inhibiting a wife from working outside the house; however, the necessity of a wife's requesting of permission for getting out of the house has been explicitly stated by jurisprudents as well as in the narrated texts. This issue has also been vividly mentioned in the practical treatise by the exegetes. The Shiite jurisprudents have recounted a wife's exiting of the husband's house without his permission as an example of disobedience and disagreement hence forbidden and Haram (MUSAVI KHOMEINI, 1995).

If a condition is set in the marriage contract for the wife's employment outside the house or if the marriage contract is essentially signed based on such a condition, the wife can keep on her job after marriage and the husband cannot prevent her from doing so (MUSAVI KHOMEINI, 2002).

If the wife has been working outside her house before marriage but she has been required in her marriage contract to resign or if the marriage contract is essentially signed based on the aforesaid condition, the wife should do so and the husband can prevent her from working outside (MUSAVI KHOMEINI, 1965).

If the wife has not been working outside the house before marriage but she demands to be employed after that, she can do so but she has to request permission from her husband for getting out of the house (MUSAVI KHOMEINI, 1995).

\section{WIFE'S PRESTIGE IN GETTING OUT OF THE HOUSE FOR DOING A NECESSARY $J O B$}

If the task being performed by a wife is compulsory for her, she is not required to ask permission from her husband for going out of the house and she can keep on her job without her husband's permission.

In an answer to the questions that what is the verdict for the women's participation in social issues such as membership in Islamic Revolutionary Guards Corps and other organizations and how would it be if such an employment reaches compulsoriness and be prohibited by the husband, Imam Khomeini (PBUH) orders that there are numerous cases and the issue can become also different in respect to the individuals' whereabouts and if such an employment becomes necessary, the husband's prohibition cannot bar it (MUSAVI KHOMEINI, 1965).

Also, in an answer to the question that whether a husband can prevent her physician wife who is an specialist in gynecology and child delivery from going out of the house, Imam Khomeini orders that a wife's going out of the house for non-compulsory affairs is suspended 
on the husband's permission and the husband has no right to prevent her from going out of the house in cases that the treatment of a patient outside the house becomes compulsory for a female physician (MUSAVI KHOMEINI, 2012).

In an answer to the question that if a husband finds it inappropriate for his wife to work outside the house and the wife's employment causes the disintegration of the marital life, can he prevent her from doing so or not, Imam Khomeini (PBUH) orders that a wife's employment is devoid of any flaws if it does not cause wastage of the husband's marital rights but going out from the husband's house is dependent on his permission (MUSAVI KHOMEINI, 2002).

\section{WIFE'S PRESTIGE IN OBSERVANCE OF HER VENERATION AND REVERENCE}

There are behaviors and duties that though not being canonically obligatory for husbands and wives are very critical in ethical terms for the cordiality of the family, solidarization of the spouses' relationships, sweetness of life, existence of serenity and amicability amongst the couples, growth and perfection of the material and spiritual affairs, tranquility and felicity of the family members such as mutual respect and veneration of each other's personality as it has been ordered by the God that "Honna Lebāson Lakom Wa Antom Lebāson Lahonna" meaning that the women of the society are the husband's chastity and cover and the husbands are the chasteness and clothing of them" (SÜRAH AL-BAQARAH, ĀYA 187).

Husbands and wives should have cordiality and amicability established between them and they should a tranquil life and they should hide each other's flaws like garments and they should protect one another's prestige and honor and they should uphold each other in the dangers and concerns. It is evident that the individual who humiliates his or her family would lose the sweetness and tranquility and comfort of his or her life as it has been ordered by the great prophet of Islam (PBUH) that "Man Estakhafa Bi Ahlehi Khasara Tayb Eyshehi" meaning "the person who belittles and humiliates his or her family would have to sustain losses in his or her enjoyment of his or her life" (RAHIMI ESFAHANI, 1993).

It has also been narrated from the great prophet (PBUH) that "Mā Akram Al-Nisā'a Ellā Karim wa Lā Ahanahonna Ella Lathim" meaning "the women are not venerated except by the magnanimous individuals and they are not humiliated except by the inferior persons" (PAYANDEH, 1998). The human veneration and dignity of a Muslim woman is the thing that has to be specifically immunized and protected by her husband and a husband should not at all perform a thing that causes insolence and downgrading of his wife. In this regard, Imam Ali 
(PBUH) orders that "Wa Lā Ta'od Bi Kerāmatehā Nafsehā" (PAYANDEH, 1998). Imam Khomeini (PBUH) always observed the veneration of his wife and his highness had ordered his lady in the very beginning that "I would like you to perform the canonical obligations and try to stay away from the forbidden things but I do not have any problem with the common things and you are free to do them or leave them undone". In his life, Imam never exercised strictness and his lady was free in coming and going and wearing garments but she was careful not to perpetrate a sin and this is reflective of Imam's subtle attention to and veneration of his wife (MUSAVI KHOMEINI, 1965).

\section{OBSERVANCE OF WIFE'S PRESTIGE IN EDUCATION RIGHT}

Islam is the religion of knowledge and cognizance and thought and pen. Invitation towards scientific growth and emphasis on the acquisition of the epistemological perfections, teaching and learning can be found in every corner of this honorable religion. The history of Islam is an expressive and undeniable testimony since its beginning of this same clear truth. His highness Imam Khomeini (PBUH) has always been in his speeches thankful and admiring of the setting saving our ladies from this closed thought that the knowledge is exclusively limited to the men and his highness invited everyone to make up for the past shortcomings: thank God, the chains tied to our beliefs have been presently broken; nowadays, all the social classes of the nation are busy educating and raising. Women are busy. The women are now busy. Now, the women are the students of the religious sciences in seminaries in Qom and other places and they are busy learning and teaching wherever they are and this is what that could only happen in this revolution. At that time, things were so restricted that women had no rights even for entering a ten-person assembly and speak about the scientific issues as well as religious matters. Nowadays, women can advertise in every corner of the country by remaining adherent to all the Islamic aspects or they can even do so outside the country. We were lagging so much behind and we should make everything up in these affairs and presently; we should compensate the shortfalls" (MUSAVI KHOMEINI, 1990).

It is for the fight against retrogressive mindsets and thoughts and in line with encouraging the compensation of the shortages and growth of science and enumeration of the Islamic revolution's accomplishments that his highness Imam emphasizes on the identicalness of the men and women in education and teaching otherwise who does not know that knowledge does not and should not have a masculine countenance in its broad sense. 
Sciences, in general, and Islamic sciences, specifically, are not devoted to a single social class and the respected Iranian ladies have proved it in the course of the revolution that they can provide valuable services to Islam and Muslims and preempt men in teaching and raising the great society of the ladies" (MUSAVI KHOMEINI, 1990).

In encouraging for development of the scientific domains and the women's scientific abilities, His Highness Imam orders that "it is now in such a way that the ladies are keeping pace with the other brothers in acquiring science and theosophy and philosophy and all the branches of science and, if God wills it, industry" (MUSAVI KHOMEINI, 1990). Somewhere else and addressing the women, His Highness orders that "be industrious in acquiring knowledge and piety for science is not uniquely specific to anyone; science belongs to everyone; piety belongs to everyone and struggling for acquiring science and piety is the duty of all of us and all of you" (MUSAVI KHOMEINI, 1990). And, this is why thousands of the decent ladies are currently educating and teaching in the various areas of Islamic sciences and in higher education centers and these all are owed to the relentless endeavors of Imam (PBUH).

\section{WIFE'S PRESTIGE IN DETERMINATION OF THE HOUSING RIGHT}

The necessity of preparation of a house for one's wife has been explicitly mentioned in some $\bar{A} Y \bar{A} T$ of the holy Quran (TALĀQ, 6). There is no doubt in the principle holding the necessity of house procurement by men; however, scientists have mentioned various explanations for it and it can be perceived from the sum of their notions that a house is a place where in a wife can spend her life and it has to be in proportion to the wife's status and her prestige and habits should be observed for providing her with a house; as an example, of a wife used to live in a personal house without partnership, she should be provided with the same type of house and the villager wives should be provided proportionately with a house (MUSAVI KHOMEINI, 1990; HA’ERI SHAH BAGH, 1997 AND DAYYANI,2000).

Article 1114 of the civil law stipulates in this regard that "a wife should reside a house specified by the husband unless the house determination is given as a right to the wife".

All of the jurisprudents, as well, believe in such a condition and it is read in jurisprudence that it is allowable to set conditions in marriage contracts for affairs agreed by the canon whether the condition be an expediency of the marriage contract itself or be it an extracontractual condition; so, if a wife sets a condition that the husband should keep her in her own hometown and not to translocate her in another city, it is to be necessarily fulfilled because it is a condition not in contradiction to the canon; moreover, if the wife sets a condition that she 
has to be allowed to live in her own personal house and not translocated to another house, her condition should be accepted (NAJAFI, 1947). However, the husband's failure in doing so and his being excused for doing so does not provide the wife with the right of unilateral revocation of the marriage contract as it holds true for the rest of the contracts (MUSAVI KHOMEINI, 1995). Imam Khomeini (PBUH) orders that "a wife has the right to be accommodated in a house she deserves according to her habits and prestige and a wife has to have a good house she needs and the wife can ask the husband to provide her with a personally owned house not partnered by other persons, second wife or others; she can be also provided with a house in which she is the only interested party; she can also ask the husband to rent a house solely for her; if a woman is from village, providing her with a rural cottage or a small pueblo that is in proportion to her status suffices her" (MUSAVI KHOMEINI, 2002).

\section{CONCLUSION}

The women's personality and prestige is not venerated the way they deserve in the society. Unfortunately, there are individuals from some schools of thought and even amongst the thinkers who do not realize women as being equal to men in human rank rather know men as the superior gender. This mindset has made women unable to attend the social arena and take part in the social and political activities. However, the present study's results indicated that Imam Khomeini (PBUH) has emphasized on the observance of the wife's prestige in his viewpoints. In numerous cases, Imam Khomeini (PBUH) is found believing that it is necessary to observe the prestige of a wife. Amongst these cases, the necessity for observing the wife's prestige in respect to the great many of the marriage's ultimate goals can be pointed out. Based thereon, Imam Khomeini believes that the wife can set a condition in the marriage contract for the husband's nonsexual enjoyment of her because marriage has a lot of ultimate goals and objectives and the conditionalization of the marriage contract on some of the cases does not cause flaws to the others. Amongst the other cases, the observance of the wife's prestige in alimony can be pointed out. Based on Imam Khomeini's perspective, if the wife has had a servant in her father's house, it is necessary for the husband to provide her with a servant in his house, as well. On the other hand, it is necessary for the husband to observe his wife's prestige in supplying her with her necessary needs. By expressing his belief in the women's right of education and employment out of the house, Imam Khomeini has also additionally emphasized in practice on the observance of the women's social prestige. 


\section{REFERENCES}

ALLAMEH HELLI, HASAN IBN YUSEF. “Mokhtalef Al-Shi'ah Fi Ahkam Al-Shari'ah", 2nd Ed., Qom, Islamic Publication Office Affiliated With Qom's Seminary, 1993.

ALLAMEH HELLI. “Tabsarah Al-Mota'allemin”, Researched By Hosseini And Yusefi, Anonymous, Faqih. 1989.

AMELI, MUHAMMAD IBN AL-HASAN, "Wasayel Al-Shi'ah", V.12, $5^{\text {th }}$ Ed., Tehran, Eslamiyyeh , 1979.

AMELI, ZAIN AL-DIN IBN ALI, “Al-Rawzeh Al-Bahiyyah Fi Sharh Al-Lam'eh AlDameshqiyyah”, V.2, $2^{\text {nd }}$ Ed., Beirut, Dar Al-Alam Al-Islami, 1983.

AROUSI AL-HAWIZI, ABD ALI IBN JOM'EH, “Interpretation Of Noor Al-Thaqalain”, V.5, Qom, Esma'eiliyan, 1995.

BAHA'EI, SHEIKH BAHA'A AL-DIN AMELI (Known As Sheikh Baha'ei), (No Date), "Jame'e Abbasi", Tehran, Farahani.

DEHKHODA, ALI AKBAR, "Dehkhoda Dictionary", V.9, Tehran University Printing And Publication Institute, 1998.

FERESHTIAN, HASAN, “The Wife's Alimony”, 2 2n Ed., Qom, Boustan-E-Ketab, 2002.

HELLI, YAHYA IBN SA'EID,, “Al-Jame'e Li Al-Sharaye'e”, Researched By Sheikh Sobhani, Qom, Sayed Al-Shohada (Alayhe Al-Salam), 1985.

JA'AFARI LANGARUDI, MUHAMMAD JA'AFAR, "Family Law", $1^{\text {st }}$ And $2^{\text {nd }}$ Editions, Tehran, Ganj-E-Danesh, 1989 And 1997.

JABA'EI AMELI, ZAIN AL-DIN (Known As Shahid-E-Thani, “Al-Rawzeh Al-Bahiyyah Fi Sharh Al-Lam'eh Al-Dameshqiyyah”, Researched By Sayed Muhammad Kalantar, Qom, Davari, 1990.

KOLAINI RAZI, MUHAMMAD IBN YA’AGHOUB, “Osul-E-Kafi”, V.1, Islamiyyeh, 1942.

MAKAREM SHIRAZI, NASER, "Nemuneh Interpretation”, V.23, Tehran, Dar Al-Kotob AlIslamiyyeh, 1995.

MIRSHAMSI, FATEMEH, "Basics of the Women's Rights and Duties in Marriage from the Imamiyyeh Jurisprudence's Perspective", Tehran, Eslamiyyeh, 2001.

MOHAQQEQ DAMAD, MUSTAFA, "Investigation Of The Family Law (Marriage And Its Dissolution)", Tehran, Islamic Sciences, 1997. 
MOHAQQEQ HELLI, ABOLGHASEM NAJM AL-DIN JA'AFAR IBN AL-HASAN, "SHARAYE'E AL-ISLAM FI MASAYEL AL-HALAL WA AL-HARAM", Researched By Sayed Sadeq Shirazi, V.2, $2^{\text {nd }}$ Ed., Qom, Esteqlal, 1989.

MUSAVI KHOMEINI, RUHOLLAH, “Tahrir Al-Wasileh”, 6 ${ }^{\text {th }}$ Ed., Qom, Dar Al-Elm, 1995.

MUSAVI KHOMEINI, RUHOLLAH, "Questions And Answers”, V.3, Qom, Islamic Publication Institute, 2002.

MUSAVI KHOMEINI, RUHOLLAH, "Sahife Noor", $1^{\text {st }}$ Ed., The Center For The Preparation And Compilation Of The Islamic Revolution's Cultural Documents, Tehran, The Center For The Publication Of The Islamic Revolution's Cultural Documents, 2012.

MUSAVI KHOMEINI, SAYED RUHOLLAH, “Imam's Sahifeh”, 22 Volumes, $4^{\text {th }}$ Ed., Tehran, The Institution For The Arrangement And Publication Of Imam Khomeini's Works, 1965.

NAJAFI, SHEIKH MUHAMMAD HASAN, “Jawaher Al-Kalam Fi Sharh Sharaye'e AlIslam", Researched By Sheikh Abbas Ghuchani, V.31, $3^{\text {rd }}$ Ed., Tehran, Dar Al-Kitab AlIslamiyyeh, 1947.

PAYANDEH, ABOLGHASEM, “Nahj Al-Fasaheh”, $3^{\text {rd }}$ Ed., Tehran, Javidan, 1998.

Trabalho recebido em 13 de agosto de 2020

Aceito em 05 de dezembro de 2020 